\section{The safer solution for babies}

Malocclusion amongst babies that use soothers has always been a concern for the profession, but the latest research suggests that posterior crossbite and anterior open bite is less prevalent when orthodontic soothers are used instead of conventional designs.

The Curaprox soother designed by Curaden and expert Dr Herbert Pick has a flat tip to prevent malocclusion and the development of an abnormally high arch.

The use of side wings helps with this

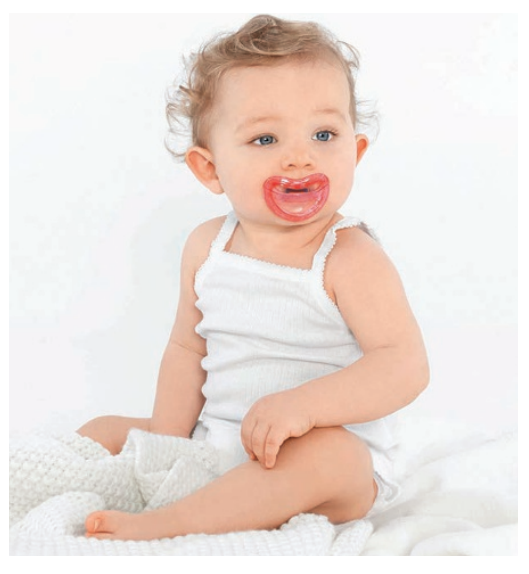

too, as they guide the suction pressure to the jaw rather than to the palate.

There are three sizes available: size 0 for 0-7 months, size 1 for 7-18 months and size 2 for 18-36 months.

So if you are looking for a safe alternative to conventional soothers to offer parents in your practice, consider the Curaprox soother - winner of the 2016 Red Dot Award.

For more information please call 01480 862084, email info@curaprox. co.uk or visit www.curaprox.co.uk.

\section{The 'Roman Emperor' of tongue cleansers}

A special edition Neoclassic AMANO 2017

has been released on the 25th anniversary of the launch of the 'original' AMANO tongue cleanser, in 1992.

Crafted from German 18/8 austenitic steel this AMANO is built to last and designed to deliver a superior tongue cleansing performance.

The $18 / 8$ refers to the proportion of chrome and nickel added to create this surgical steel alloy [because the Neoclassic AMANO is made from 18/8 austenitic steel it can be placed in an autoclave to achieve perfect sterilisation, if so desired. A simple rinse under a hot tap after use will also suffice].

As with the original AMANO the design of the scraper head is slightly 'sharper' than for the core AMANO range. So this AMANO will particularly appeal to seasoned advocates of tongue scraping.

Mano Manoharan, the creator of the AMANO, has taken the opportunity to pay

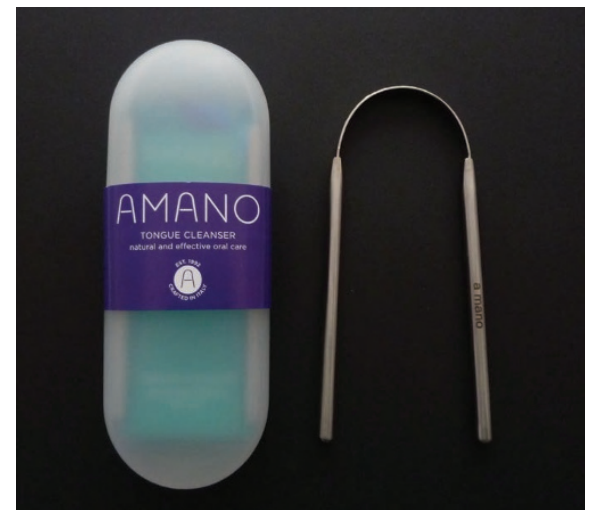

homage to the earliest known adopters of the ancient and noble art of tongue scraping. So the packaging wrap chosen for the Neoclassic AMANO 2017 is Imperial Purple - the very same colour worn by the Roman Emperors.

For more information visit www. amanotonguecleanser.com. The Neoclassic AMANO is now available at John Bell \& Croyden.

\section{The latest goodwill results}

Dental Elite is pleased to announce that its mid-year goodwill results for the financial year ending March 2017 are now available, and are showing that demand is as strong as ever before. This is especially true for NHS contracts in London and the South East where percentage of turnover has surpassed $200 \%$ for the first time ever.

In terms of EBITDA - which is earnings before interest, taxes, depreciation and amortisation - the typical multiple has fallen from $6.8 \times$ to $6.46 \times$. The average adjusted net profit (ANP), which represents the best estimate of what a practice's true profit will be and indicates how much a business would be worth to a new owner, is $3.19 \times$ this time round.

All in all, the mid-year results have been generally quite positive with no big surprises or upsets. What Dental Elite have seen is that goodwill values have started to stabilise, so if you are thinking of buying or selling a practice you will need to keep an eye out for potential changes.

For help deciphering how the latest findings affect you and more information on how goodwill values are calculated, get in touch with Dental Elite. Visit www.dentalelite.co.uk or call 01788545900.

\title{
Dedicated to supplying the best products available
}

As part of its dedicated service to dentists, Surgery Express always strives to supply the very best products available. The team is always on the look out for the latest technologies and innovations that could help practitioners enhance their everyday practice and deliver spectacular care to patients.

As such, the Surgery Express team were at the ADI Team Congress in March to tell dentists about their new range of implant systems from TBR. As its first step into dental implantology, Surgery Express wanted to be able to provide a system with renowned quality, exceptional support and unmatched clinical performance. TBR, with its flagship implant, the Z1, was the perfect choice.

A unique implant system, the $\mathrm{Z} 1$ from TBR features an innovative titanium-zirconia construction. The titanium shaft ensures predictable and secure osseointegration, while the zirconia collar sits at tissue level and enhances epithelial healing, microbial resistance and aesthetics.

As exclusive suppliers of TBR implants in the UK, Surgery Express are incredibly excited to work alongside those dentists who already use and love the $\mathrm{Z1}$ implant - and look forward to forging new partnerships with many more aspiring implant professionals in the future.

For more information, visit http://z1implants.co.uk/, call 08006888992 or email sales@surgery-express.co.uk. 